\title{
Importance of small fishes and invasive crayfish in otter Lutra lutra diet in an English chalk stream
}

\author{
J. Robert Britton ${ }^{1, *}$, Matthew Berry ${ }^{1}$, Samantha Sewell ${ }^{1}$, Corina Lees ${ }^{1}$ and Peter Reading ${ }^{2}$ \\ ${ }^{1}$ Department of Life and Environmental Sciences, Faculty of Science and Technology, Bournemouth University, Fern Barrow, \\ Poole BH12 5BB, UK \\ 217 Mayford Road, Poole, Dorset BH12 1PT, UK
}

\begin{abstract}
The diet composition of the European otter Lutra lutra was assessed using spraint analysis in the Hampshire Avon, a lowland chalk stream in Southern England, over an 18-month period. Small cyprinid fishes were the main prey item taken in all seasons, with bullhead Cottus gobio and stone loach Barbatula barbatula also important; there were relatively few larger fishes of interest to fisheries found. There were significant seasonal differences in diet composition by season, with signal crayfish Pacifastacus leniusculus only being prominent prey items in warmer months and amphibians in winter, revealing that non-fish resources were seasonally important dietary components. Reconstructed body lengths of prey revealed the only species present in diet $>350 \mathrm{~mm}$ was pike Esox lucius. These dietary data thus provide important information for informing conservation conflicts between otters and fishery interests.
\end{abstract}

Keywords: otter spraint / Barbus barbus / angling / conservation conflict

\begin{abstract}
Résumé - Importance des petits poissons et des écrevisses envahissantes dans le régime alimentaire de la loutre Lutra lutra dans une rivière calcaire anglaise. La composition du régime de la loutre Lutra lutra a été évaluée à l'aide d'une analyse des épreintes dans le Hampshire Avon, un cours d'eau calcaire de plaine dans le sud de l'Angleterre, sur une période de 18 mois. Les petits poissons cyprinidés ont été les principales espèces de proies prises en toutes saisons, avec le chabot Cottus gobio et la loche franche Barbatula barbatula également fréquents; il y avait relativement peu de plus grands poissons d'intérêt pour les pêcheries. Il y avait des différences saisonnières significatives dans la composition de régime, avec l'écrevisse signal Pacifastacus leniusculus n'étant qu'une proie fréquente pendant les mois les plus chauds et les amphibiens en hiver, révélant que les ressources autres que le poisson étaient des composants alimentaires saisonnièrement importants. Des longueurs de proies reconstituées ont révélé que la seule espèce de taille $>350 \mathrm{~mm}$ présente dans le régime était le brochet Esox lucius. Ces données alimentaires fournissent donc des connaissances importantes pour informer les conflits de conservation entre les loutres et les intérêts de pêche.
\end{abstract}

Mots clés : épreinte de loutre / Barbus barbus / pêche à la ligne / conflit de conservation

\section{Introduction}

The conservation of aquatic apex predators often results in conflict between their protection and the recreational and economic exploitation of natural resources, such as fisheries and aquaculture (Rauschmayer et al., 2008). At freshwater aquaculture sites across Europe, conflicts with piscivorous fauna, such as otter Lutra lutra have been widely reported (e.g., Kloskowski, 2005, 2011). In freshwaters with less

\footnotetext{
*Corresponding author: rbritton@bournemouth.ac.uk
}

intensive management, such as ponds and rivers used for catch and release recreational angling, anglers frequently report fish losses to otter predation as a major concern, specifically for the loss of larger bodied fishes (Britton et al., 2005; Almeida et al., 2012). Where dietary data are available, however, they suggest that these fishes are a minor component of their diet, with species including eel Anguilla anguilla and bullhead Cottus gobio more commonly taken (Britton et al., 2006; Grant and Harrington, 2015).

Despite these conflicts between piscivorous fauna and users of fishery resources, otters potentially provide some ecological benefits via their predation of invasive fauna. For 


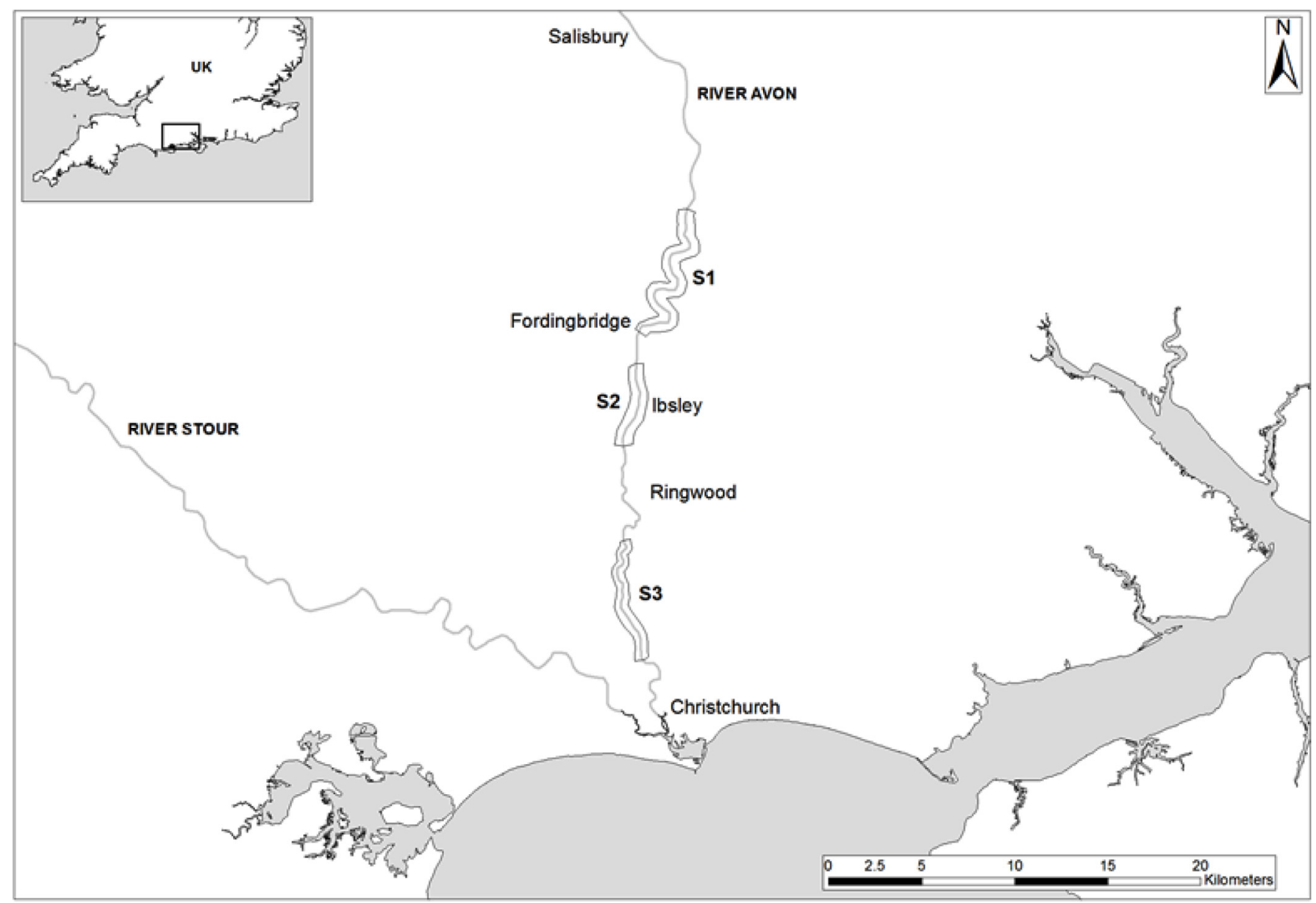

Fig. 1. Inset: Location of the Hampshire Avon in the UK. Main: The three sections (S1-S3) of the river where the spraints were collected.

example, in Southern Europe, the invasive Louisiana Red Claw Crayfish Procambarus clarkii has been reported the main prey of several piscivorous species, including otters (e.g., Beja, 1996) and birds (Rodríguez et al., 2005). In Portugal, P. clarkii predation by otters was more intense in spring, summer and autumn than in winter, and was directed towards larger and heavier individuals (Correia, 2001). In Kenya, the diet of the African clawless otter Aonyx capensis has also been used to indicate the extent of $P$. clarkii dispersal (Ogada et al., 2009). This predation on invasive crayfishes could thus potentially provide some biotic resistance against their invasions.

In England, legal protections and the implementation of controls in the use of pesticides and PCBs, have enabled otter populations to recover in many river catchments (Chanin, 2003). Although otters generally have low densities and large home ranges within river catchments (Durbin, 1996), their sporadic predation of large fishes (e.g., Britton et al., 2005) continues to raise considerable concern among fishery interests over their impact on fish stocks in lowland British rivers. Many of these catchments are also invaded by signal crayfish Pacifastacus leniusculus (Holdich and Reeve, 1991). Despite these issues, there is often little contemporary information in many of these catchments on otter diet composition. Consequently, the aim here was to assess the species and body sizes of fish depredated by otters in lowland British chalk stream over an 18-month period using spraint analysis. This then enabled exploration of the interaction of otters with both invasive crayfish and the fish species of angling interest in this river.

The study river was the Hampshire Avon, a chalk stream with high conservation designations (Natural England, 2016). The river rises above the city of Salisbury (N51:03:40, W1:48:00) and enters the sea downstream of the town of Christchurch (N50:43:24; W1:44:32). Otter spraint were collected from three accessible sections of the river between these two locations between February 2014 and July 2015 (Fig. 1). Spraint collection was generally once per week, involving a single visit to one of the accessible sections, with searching around typical otter marking sites, such as large stones in the riparian zone (Smiroldo et al., 2009). As these river sections were not sufficiently spatially discrete to avoid otters moving between them during their daily movements (Chanin, 2003; Fig. 1), then for analyses, dietary data were combined across the sections. Across the three river sections, widths were to $20 \mathrm{~m}$ and depths to $2 \mathrm{~m}$. For a flow gauging station in Section 3 (Fig. 1), mean flow between 1975 and 2015 was $20.3 \mathrm{~m}^{3} \mathrm{~s}^{-1}$, Q95 (flow exceeded $95 \%$ of the time) was $6.2 \mathrm{~m}^{3} \mathrm{~s}^{-1}$, Q50 (flow exceed $50 \%$ of the time) was $14.7 \mathrm{~m}^{3} \mathrm{~s}^{-1}$, and Q10 (flow exceed $10 \%$ of the time) was $39.2 \mathrm{~m}^{3} \mathrm{~s}^{-1}(\mathrm{CEH}, 2016)$. Due to the size and flow regime of 
the river, electric fishing is difficult to utilise, resulting in negligible quantitative data on the fish assemblage. However, angler catches indicate roach Rutilus rutilus, chub Squalius cephalus and barbel Barbus barbus are important target species (unpublished data), with minnow Phoxinus phoxinus numerically dominant. A recent study on the river assumed P. leniusculus were absent from the river (Basić et al., 2015).

Following their collection, the spraints were dried and held in paper envelopes. In the laboratory, dried spraints were soaked overnight prior to being rinsed and sorted. Identifications of prey items were from key bones and scales sorted from the spraints, and examined under a dissecting microscope ( $\times 5$ to $\times 45$ magnification) (Britton et al., 2006). Prey items were identified to the lowest taxonomic group possible. They were grouped into the following prey categories: cyprinids, salmonids, amphibian (primarily identified as frogs, Rana spp.), bullhead, stone loach Barbatula barbatula, signal crayfish Pacifastacus leniusculus, birds, pike (Esox lucius), perch (Perca fluviatilis) and eel (Anguilla anguilla). Whilst some species-specific identification was possible for the cyprinid species from scales, this was only for a proportion of spraints. Thus, other than for length reconstruction, their data were combined into 'cyprinids'.

For each prey category, spraint data were analysed according to their 'relative abundance'. This was calculated as: $\left(\Sigma S_{i} / \Sigma S_{\mathrm{t}}\right) \times 100$, where $S_{i}=$ the number of items in spraints composed of prey $i$ and $S_{t}=$ the total number of items in spraints in the entire sample. These calculations were completed for the entire data set and then by season, described as follows: winter: December-March; spring: April-June; summer: July-September; autumn: October and November. Using the raw frequency data, the null hypothesis was initially tested that the relationship between season and the relative abundance of the prey categories in otter diet was not significant using a chi-square test for independence. To then test the effect of season on the relative abundance of each prey category, the relative abundance of each prey category per spraint was determined, with these data then grouped by season and tested in generalized linear models (GLM), as transformation was unable to normalise the data. In each model, the dependent variable was relative abundances of the prey category and the independent variable was season. Model outputs were the overall significance of the test, the mean relative abundance of the prey category per season and the significance of differences between seasons according to linearly independent pairwise comparisons with Bonferroni adjustment for multiple comparisons. Initially, seasonal data in different years were used separately, but as all models revealed no significant differences between years by season $(P>0.05$ in all cases), then final models combined data across the years. Similarly, this enabled the seasonal data to be combined across the years for the chi-square test for independence.

For the $S$. cephalus, $R$. rutilis, E. lucius and P. fluviatilis that were identified from their scales, their body lengths were estimated through measuring their scale radius (SR) to predict their fish length (fork length, Lf) from $\mathrm{Lf}=b \mathrm{SR}+a$, where $a$ and $b$ were the constants from the species-specific regression relationship between scale radius and fish length (Britton and Shepherd, 2005). Differences in lengths between the species were tested using ANOVA, with Tukeys post hoc tests testing for significance of differences between the species.
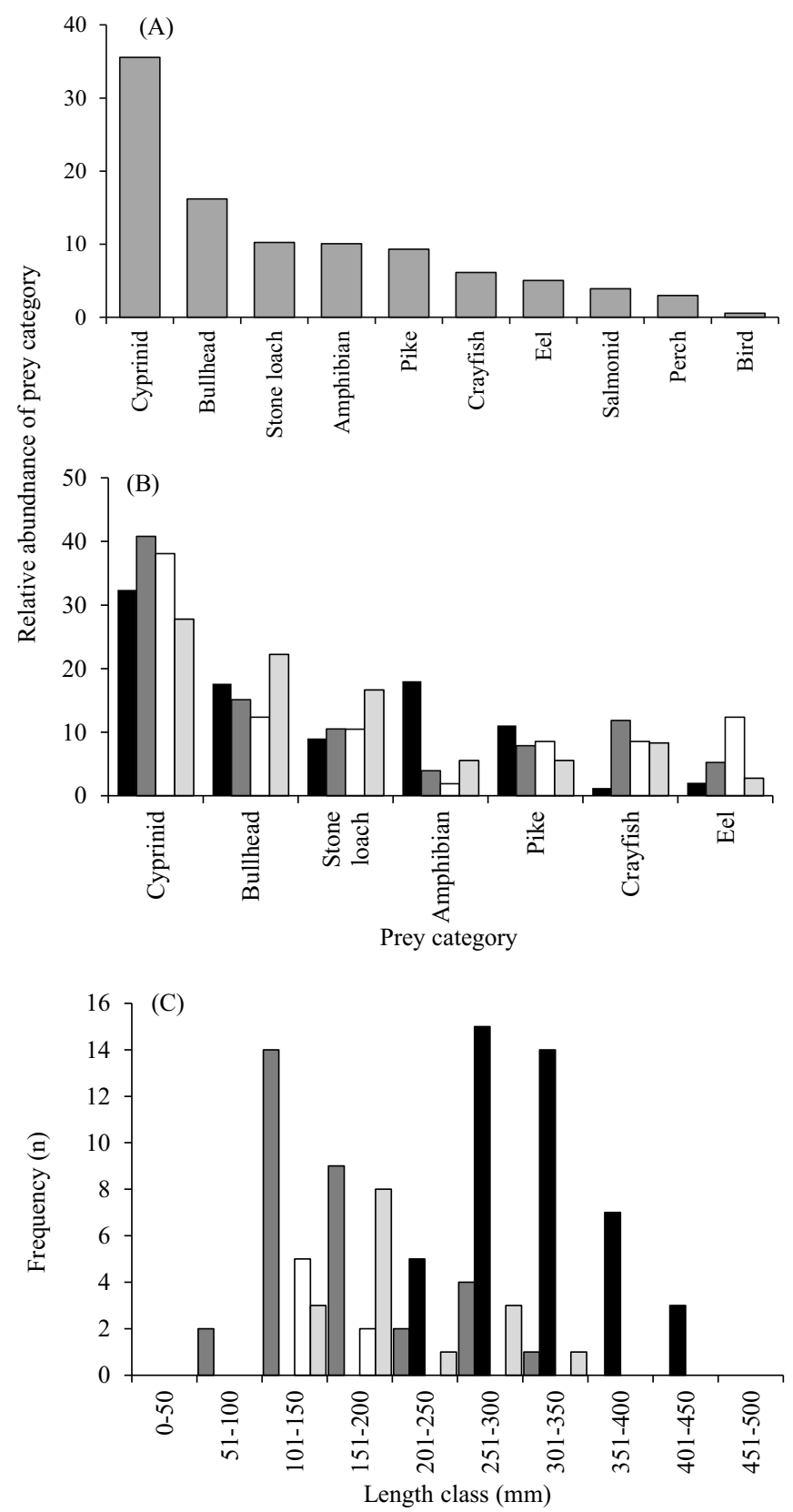

Fig. 2. (A) Relative abundance of major prey items in the spraints; (B) relative abundance of major prey items in the spraints by season, where black bars: winter; dark grey: spring; white: summer; and light grey: autumn; and $(\mathrm{C})$ reconstructed length frequency distribution of cyprinid fishes identified in the spraints, as identified and estimated from scales. Dark grey bars: chub Squalius cephalus $(n=32)$; clear bars: roach Rutilus rutilis $(n=7)$; black bars: pike Esox lucius $(n=50)$; light grey bars: Perca fluviatilis $(n=16)$.

A total of 140 spraints were analysed, with 535 prey items identified and categorised into one of the 10 prey categories. Relative abundance revealed that, overall, cyprinid fishes were the most abundant item in spraints, with bullhead, stone loach, amphibians and pike also being relatively common in diet (Fig. 2A). The chi-square test for independence testing the effect of season on relative abundance was significant $\left(\chi^{2}=88.6\right.$, d.f. $\left.=27, P<0.01\right)$ and thus the null hypotheses 
that season had no effect on relative abundance was rejected. The GLMs testing the effect of season on the relative abundance of each prey category revealed that there were no significant seasonal differences for cyprinids (Wald $\chi^{2}=7.18$, $P=0.20$ ), stone loach (Wald $\chi^{2}=5.79, P=0.13$ ) and pike (Wald $\chi^{2}=1.71, P=0.64$ ) (Fig. 2B). There were, however, significant seasonal differences for bullhead (Wald $\chi^{2}=18.92$, $P<0.01$ ), amphibians (Wald $\chi^{2}=18.67, P<0.01$ ), signal crayfish (Wald $\chi^{2}=12.48, P<0.01$ ) and eel (Wald $\chi^{2}=15.82$, $P<0.01$ ) (Fig. 2B). Significantly higher proportions of bullheads and amphibians were taken in autumn and winter than in spring and summer $(P<0.05$ in all cases) (Fig. 2B). The relative abundance of signal crayfish was significantly lower in winter than any other season $(P<0.05$ in all cases) and for eel, their relative abundance was significantly higher in summer than any other season $(P<0.05$ in all cases) (Fig. 2B). The reconstructed fish lengths from scales revealed differences in lengths of species predated by otters $\left(F_{3,101}=300.80\right.$, $P<0.01$ ), although post-hoc tests revealed the significant differences were only between $E$. lucius (mean length $306 \pm 29 \mathrm{~mm})$ and all other fishes $(P<0.01)$. All differences between the other species were not significant $(S$. cephalus: $141 \pm 12 \mathrm{~mm}$; R. rutilus $138 \pm 9 \mathrm{~mm}$; P. fluviatilis $161 \pm 16 \mathrm{~mm}$; $P>0.05$ ) (Fig. 2C). Only one B. barbus was identified from scale remains, a fish of estimated length $245 \mathrm{~mm}$.

This dominance of relatively small fish in otter diet in the Hampshire Avon was consistent with other studies in temperate European regions (Clavero et al., 2003), including studies based on stomach contents (Britton et al., 2006; Lanszki et al., 2015). These results were also consistent with recent studies in Great Britain, such as for the River Thames, where C. gobio was the most frequent prey item in summer and cyprinids in winter (Grant and Harrington, 2015). Where larger cyprinids were present in spraints, they could be identified to species level from scales and revealed that although $S$. cephalus were taken regularly, although $S$. cephalus were taken regularly, they were rarely taken at sizes over $200 \mathrm{~mm}$. Only one B. barbus was identified as present in spraints, with this again being a relatively small fish for the species. Of other angler-targeted species in the spraints, only E. lucius was relatively prominent, present in $31 \%$ of all spraints with fish of estimated lengths of 201 to $434 \mathrm{~mm}$ taken (age $0+$ to $3+$ years). Although studies have revealed otters in Great Britain can predate upon salmonid fishes of up to $900 \mathrm{~mm}$ and Cyprinus carpio up to $730 \mathrm{~mm}$ (Carss et al., 1990; Britton et al., 2005), no fish of these sizes were detected in the spraints. This is despite E. lucius being present in the river to lengths of over $1000 \mathrm{~mm}$ and B. barbus to over $700 \mathrm{~mm}$. Notwithstanding, Kloskowski et al. (2000) suggested that bones from larger fishes, such as C. carpio, are often under-represented in spraints and thus if larger fish were taken by otters within the study area then it might be that the methods used were not able to detect these. The lack of quantitative data on the fish assemblage also prevented the use of analytical methods such as relative frequency of occurrence and relative size frequency distributions (Carss and Parkinson, 1996). Thus, if managers require greater insights into otter predation in the river, then these potential confounding issues need to be addressed through further study.
Studies on otter diet have generally suggested their predation pressure on non-native fishes is low. For example, in the Somerset Levels, England, a low lying area approximately $100 \mathrm{~km}$ to the north-east of the Hampshire Avon, and where the rivers have highly regulated flows, otter diet was dominated by $A$. anguilla and three-spine stickleback Gasterosteus aculeatus (L.). The non-native C. carpio and sunbleak Leucaspius delineatus were rarely present in diet, and pumpkinseed Lepomis gibbosus was never recorded, despite these non-native species all being present in relatively high abundances in some water bodies in the area (Miranda et al., 2008). Along the Hampshire Avon flood plain, there are numerous water filled former gravel workings now used as recreational fisheries, with $C$. carpio and European catfish Silurus glanis L. both being present. However, neither species was recorded in the spraints. By contrast, P. leniusculus was present in spraints, particularly in the warmer months, despite previous work suggesting they were absent. The abundance of crayfish in spraints in summer was consistent with other European studies that have suggested invasive $P$. clarkii are a potentially important prey item (Beja, 1996), but with predation intensity low in winter (Correia, 2001). However, the proportion of crayfish encountered in other studies was considerably higher than here. For example, Beja (1996) reported an overall relative contribution in number of $24.4 \%$ in Iberian streams versus 6\% in the Hampshire Avon. Adrian and Delibes (1987) reported that crayfish were found in $80 \%$ of all spraints collected in the Doñana National Park, Spain, whereas in the Hampshire Avon, crayfish remains were found in $26 \%$ of all spraints. In entirety, this suggests that $P$. leniusculus might have been still in relatively low abundance in the Hampshire Avon and so as their population establishes and becomes more abundant, their contribution to otter diet is likely to increase.

These temporal and spatial analyses of otter diet in this lowland chalk river thus provide some important knowledge and management outputs. They revealed that invasive $P$. leniusculus have dispersed throughout much of the river and indicated that, in summer at least, otter spraint analyses can represent a cost-effective method to monitor their distribution that could complement more resource intensive methods such as trapping. This result emphasised that non-fish resources can be important dietary components for otters. The results also indicated that prey items in spraints were rarely from fishes of interest to recreational fisheries and, when they were, their lengths were generally outside of angling interest.

Acknowledgements. We thank John Levell for his assistance in spraint collection and Sarah Young for assistance in the laboratory.

\section{References}

Adrian MI, Delibes M. 1987. Food habits of the otter (Lutra lutra) in two habitats of the Doñana National Park, SW Spain. J Zool 212: 399-406.

Almeida D, Copp GH, Masson L, Miranda R, Murai M, Sayer CD. 2012. Changes in the diet of a recovering Eurasian otter population between the 1970s and 2010. Aquat Conserv Mar Freshw Ecosyst 22: $26-35$. 
Basić T, Britton JR, Jackson MC, Reading P, Grey J. 2015. Angling baits and invasive crayfish as important trophic subsidies for a large cyprinid fish. Aquat Sci 77: 153-160.

Beja PR. 1996. An analysis of otter Lutra lutra predation on introduced American crayfish Procambarus clarkii in Iberian streams. J Appl Ecol 33: 1156-1170.

Britton JR, Shepherd JS. 2005. Biometric data to facilitate the diet reconstruction of piscivorous fauna. Folia Zool 54: 193-200.

Britton JR, Shepherd JS, Toms S, Simpson V. 2005. Presence of carp, Cyprinus carpio, in the diet of the otter, Lutra lutra. Fish Manag Ecol 12: 221-223

Britton JR, Pegg J, Shepherd JS, Toms S. 2006. Revealing the prey items of the otter Lutra lutra in South West England using stomach contents analysis. Folia Zool 55: 167-174.

Carss DN, Parkinson SG. 1996. Errors associated with otter Lutra lutra faecal analysis. I. Assessing general diet from spraints. J Zool 238: 301-317.

Carss DN, Kruuk H, Conroy JWH. 1990. Predation on adult Atlantic salmon, Salmo salar L., by otters, Lutra lutra (L.), within the River Dee system, Aberdeenshire, Scotland. J Fish Biol 37: 935-944.

CEH. 2016. 43021-Avon at Knapp Mill. http://nrfa.ceh.ac.uk/data/ station/meanflow/43021. Last accessed 05/12/16.

Chanin P. 2003. Monitoring the Otter Lutra lutra. Conserving Natura 2000 Rivers Monitoring Series No. 10. Peterborough: English Nature.

Clavero M, Prenda J, Delibes M. 2003. Trophic diversity of the otter (Lutra lutra L.) in temperate and Mediterranean freshwater habitats. J Biogeog 30: 761-769.

Correia AM. 2001. Seasonal and interspecific evaluation of predation by mammals and birds on the introduced red swamp crayfish Procambarus clarkii (Crustacea, Cambaridae) in a freshwater marsh (Portugal). J Zool 255: 533-541.

Durbin LS. 1996. Some changes in the habitat use of a free-ranging female otter Lutra lutra during breeding. J Zool 240: 761-764.

Grant KR, Harrington LA. 2015. Fish selection by riverine Eurasian otters in lowland England. Mammal Res 60: 217-231.
Holdich DM, Reeve ID. 1991. Distribution of freshwater crayfish in the British Isles, with particular reference to crayfish plague, alien introductions and water quality. Aquat Conserv Mar Freshw Ecol 1: 139-158.

Kloskowski J. 2005. Otter Lutra lutra damage at farmed fisheries in southeastern Poland. I: An interview survey. Wildlife Biol 11: 201-206.

Kloskowski J. 2011. Human-wildlife conflicts at pond fisheries in eastern Poland: perceptions and management of wildlife damage. Eur J Wild Res 57: 295-304.

Kloskowski J, Grendel A, Wronka M. 2000. The use of fish bones of three farm fish species in diet analysis of the Eurasian otter, Lutra lutra. Folia Zool 49: 183-190.

Lanszki J, Bauer-Haáz ÉA, Széles GL, Heltai M. 2015. Diet and feeding habits of the Eurasian otter (Lutra lutra): experiences from post mortem analysis. Mamm Study 40: 1-11.

Miranda R, Copp GH, Williams J, Beyer K, Gozlan RE. 2008. Do Eurasian otters Lutra lutra (L.) in the Somerset Levels prey preferentially on non-native fish species? Fund Appl Limnol 172: 339-347.

Natural England. 2016. River Avon System. http://www.sssi.natural england.org.uk/citation/citation_photo/2000183.pdf. Last accessed $28 / 03 / 2016$

Ogada MO, Aloo PA, Muruthi PM. 2009. The African clawless otter Aonyx capensis (Schinz, 1821) and its diet as an indicator of crayfish invasion dynamics in aquatic systems. Afr J Ecol 47: 119-120.

Rauschmayer F, Wittmer H, Berghöfer A. 2008. Institutional challenges for resolving conflicts between fisheries and endangered species conservation. Mar Policy 32: 178-188.

Rodríguez CF, Bécares E, Fernández-Aláez M, Fernández-Aláez C. 2005. Loss of diversity and degradation of wetlands as a result of introducing exotic crayfish. In: Zilletti B, Capdevila-Arguelles L, eds. Issues in Bioinvasion Science. Netherlands: Springer, pp. 75-85.

Smiroldo G, Balestrieri A, Remonti L, Prigioni, C. 2009. Seasonal and habitat-related variation of otter Lutra lutra diet in a Mediterranean river catchment (Italy). Folia Zool 58: 87-97.

Cite this article as: Britton JR, Berry M, Sewell S, Lees C, Reading P. 2017. Importance of small fishes and invasive crayfish in otter Lutra lutra diet in an English chalk stream. Knowl. Manag. Aquat. Ecosyst., 418, 13. 